\title{
4. Costa Rica as pioneer of a green social contract
}

\author{
Monica Araya
}

\section{INTRODUCTION}

As society aims to combat climate change and inequality, Costa Rica offers the rare story of a small country that has over the years made bold decisions to address environmental and social problems. This chapter first outlines these bold choices and the significance of their legacy today as the country pursues a green economy with zero emissions, resilient and fair. Good public policies have made a difference, but local environmental activists have also played a pivotal role at key moments. Thanks to their efforts, Costa Rica reversed the decision to support oil-drilling plans by a US company, open-pit gold mining by a Canadian company and to build an oil refinery as part of a loan from China. Costa Rican civil society has also played a pioneering role in the promotion of zero-emissions electric mobility.

The chapter also looks at early efforts to promote carbon neutrality and why the Paris Agreement helped reset the button in Costa Rica by encouraging a framework for deeper decarbonization, not just carbon neutrality that is achieved through forest offsets that compensate previous emissions. The process leading to the Paris Agreement of 2015 helped Costa Rica rethink its national targets, opened the process for public discussion and engage a variety of stakeholders.

The third section focuses on the current developments. It looks at the efforts to make decarbonization a pillar of the narrative and governmental plans both the National Development Plan and the National Decarbonization Plan to 2050. It looks at the logic of the National Decarbonization Plan and at how it integrates fairness and inclusiveness. The final section offers a brief reflection.

\section{A HISTORY OF BOLD DECISIONS}

Costa Rica's story of making bold decisions over the years could be instructive in the debate of how to win support for a greener and more inclusive economy. 
The country made transformative decisions in the 1940s that opened the door for making bold choices later. Although Costa Rica is celebrated for protecting biodiversity and running on renewable electricity, the bold ideas that set the country on a distinct trajectory focused on protecting and investing in people, which in turn provided the political stability needed to make bold decisions, later on, to protect nature and pursue carbon neutrality.

\section{Social Progress and Green Growth}

The audacious decision to abolish the army in Costa Rica in 1948 - in a region where the military have had so much clout - freed up fiscal resources that went to social welfare and, perhaps even more important, having no army spared Costa Ricans from traumatic armed conflicts that have harmed so many Latin Americans over the years. Before that decision, social legislation had given workers a set of "social guarantees" in 1943, which included a critical right: universal access to free healthcare. This visionary approach to legislation protected workers from potential abuses from economic elites. One hundred years earlier, access to free public education had been guaranteed as well. Costa Rica was one of the first countries to grant education rights to women. Today, by constitutional obligation, the country must invest 8 percent of GDP in public education. Many of these social victories shaped the society. Today, with so much debate around inequality, amid social protests, Costa Rica's early investment in a social contract is a central part of the story.

Another bold decision was made in the 1970s: to invest in forest protection by creating a system of national parks. The timing of this decision is curious because it was made right when the logic of conquering nature for the sake of development and industrialization prevailed in the then-called "Third World". By the 1980s and early 1990s, cattle ranching had become a driver of deforestation. The mid-1990s marked a watershed because Costa Rica managed to reverse deforestation while growing the population and the economy. A system of payment for environmental services was pioneered to compensate owners of farms for not cutting trees and for preserving ecosystem services, such as watershed protection. Being the first country to reverse tropical deforestation shaped an enduring political narrative of green growth in which environmental protection and growth were not seen as clashing goals.

Today, Costa Rica runs on nearly 100 percent renewable electricity. Non-fossil-fuel power generation goes back several decades. Technically, economically and psychologically - this attribute has been a launching pad for going further in other sectors - for example, transportation. Because nearly 100 percent of the electricity comes from five renewable sources - hydropower, geothermal, wind, biomass and sun - Costa Rica is ideal for electric mobility (see the final section). In 2019, the state-owned utility discontinued plans to 
build the last hydropower dam, thus closing an era of hydropower investments. A major focus on diversity has been underway, with strong emphasis on geothermal and wind generation, which today represent 15 percent and 12 percent of power generation, respectively. Renewable electricity has also become a pillar of a green-economy discourse combining of elements of identity - "the country of renewable energy".

This rationale of differentiation - Costa Rica as a green economy with social stability - has been beneficial to attract tourism and generate income. In a small country of 5 million people, tourism has a direct contribution to the gross domestic product (GDP) of about 6.5 percent (the indirect contribution is 8 percent).

\section{Bold Activism}

Despite positive developments, tensions have emerged as in any other country. Over the years, some politicians have tried to put Costa Rica on a less green pathway. It is important to underscore the role that activism played whenever the country was at the brink of making mistakes. Three controversial proposals were made over a decade between 2002 and 2013: (1) to open Costa Rica for oil drilling; (2) to grant rights for gold mining; and (3) to take a loan from China to co-operate a $\$ 1.5$ billion oil refinery.

The dream of prosperity through oil wealth and mining has never left some sectors in Costa Rica that view social and environmental regulations as expensive burdens that make Costa Rica more expensive for business compared to others in Central America. Often these voices promote a more traditional, dirtier, approach to growth - such as oil and gas as well as mining. Environmentalists have stopped these projects. Bold activists and conservationists should be recognized for fighting politicians that have betrayed the vision of green economy with a respectable social contract. At times, life for activists and whistleblowers in Costa Rica has been difficult and a few even lost their lives. Environmentalism between 2001 and 2013 saved Costa Rica from making "U-turns" on environmental issues.

First, the country has had a moratorium on oil exploration and drilling since the 2002. This is the direct result of an environmental coalition of activists and experts. Although this ban on drilling is not law, it has survived five administrations from three political parties: the Chinchilla administration (2010-14) extended it in 2011 with Executive Order 36693; the Solis administration (2014-18) extended it to 2021. In February 2019, President Alvarado extended the moratorium to 31 December of 2050 through Executive Order 41578.

Second, the country does not support mining activities. In November 2010, environmental activists helped overturn the push for gold mining by President Oscar Arias (2006-10) who had passed an executive order declaring the 
project in the "national interest". A tribunal stopped the project and ordered the company to compensate Costa Rica for the environmental impacts caused during the exploration. For the first time, a country in Latin America blocked future open-pit mineral mining: Congress adjusted the mineral law to prevent similar cases in the future.

Finally, in June 2013, activists, legal experts and Congress representatives also succeeded in making the government reverse its decision to take a loan from China to jointly own an oil refinery. Costa Rican experts from various backgrounds - law, economics, climate - argued the case against the governmental plans and lobbied against the loan: ethical concerns, constitutional reasons, and environmental concerns - including its contradiction to Costa Rica's narrative around green growth. The final blow came from an independent body in June 2013 - the National Comptroller Office - when it rejected the project and the president had no green light to take a loan. The project was at a standstill for months and the following administration agreed to terminate it for good.

\section{CARBON NEUTRALITY: PARIS AGREEMENT AS "GAME CHANGER"}

On the road to the UN Climate Change Conference in Copenhagen, "COP15", in 2009, Costa Rica announced a goal to become carbon neutral. This vision took many by surprise and was announced without an execution plan. There was no clear pathway to achieve this aspirational goal and this period of bold vision with uncertainty culminated with the process leading to the UN Climate Change Conference in Paris, "COP21" in 2015. This is because each country was expected to have a plan and submit it as a contribution to the international community. Put simply, the logic of Paris Agreement helped Costa Rica put its house in order.

\section{Carbon Neutrality Prior to Paris}

Prior to Paris, Costa Rica had embraced "carbon neutrality" - which was the right instinct - at a time when other developing countries did not want to reduce their emissions. Back then, the Kyoto Protocol provided the international rules of engagement: only developed countries were obliged to cut emissions.

Costa Rica went alone and presented this vision at the COP15 in Copenhagen. The foundation underpinning carbon neutrality was acceptable at the time because no one was doing it and there was no simple way of achieving it. But the problem was that it was too heavily oriented toward the use of "carbon offsets" - which dominated the thinking back then. Costa Rica encouraged companies to reduce their environmental footprint and to "neutralize" emis- 
sions by supporting sustainable forest projects. The main legacy from those early days was the positive approach to climate action - countries wanted to be certified as "carbon neutral" - in contrast with corporate approaches in other economies that present climate action as a burden to profits. The most concrete legacy from that phase was the delivery of the world's "carbon-neutral coffee" since 2011. Pioneered by a rural cooperative of over 900 coffee farmers, Coopedota has evolved into an internationally recognized organization. Today the Ministry of Agriculture runs a project for the sector that is inspired by its early actions.

\section{Paris Reset the Button in Costa Rica}

The climate policy button was then reset on the road to Paris. The preparation for COP21 in Paris inspired several consultations to discuss the logic and scope of the national contribution to the Paris Agreement, and a more far-reaching approach by opening up a new debate on ways to achieve absolute reductions of greenhouse gases - for example, the need for an electric train - as opposed to previous debates that had operated under a more narrow logic of carbon offsets.

Costa Rica's Paris target was set as follows: to cut 25 percent of its greenhouse gas emissions to 2012 levels, which means a 44 percent emissions reduction compared to the business-as-usual scenario. The target received good international assessments, becoming one of the few countries in the developing world to offer an absolute reduction according to the global initiative, Climate Action Tracker. Today, the target is under revision to ensure it is aligned with the $1.5^{\circ} \mathrm{C}$ temperature imperative of the Paris Agreement. Another positive legacy from the process leading to the Paris Agreement was the creation of two councils on climate change: one made up of citizens and the other made up of scientists.

The road to Paris also energized civil society in Costa Rica. In June 2015, the first-ever consultation with Costa Rican citizens took place on climate change, organized by Costa Rica Limpia and the international organization World Wide Views, and bringing together citizens from the seven provinces. The results were shared with the Ministry of Environment and Energy as it prepared for COP21. Prior to the Paris Agreement, the citizen dimension had been absent from debates around carbon neutrality.

In addition to the debates around Paris and the new national reduction target, in 2015 public consultations were also carried out for the first time to provide feedback for the new National Energy Plan (2015-30). It included measures for power generation, efficiency, renewables and fuels. For the first time it integrated goals for transportation - the largest emitter in Costa Rica. For the 
first time, the Energy Plan set objectives to clean up fleets, public transit and promote much cleaner fuels.

Since 2015, the need to invest in sustainable transportation has gained prominence in the national debate. The Paris Agreement gave impetus to local advocates and Congress representatives to kickstart a debate around electrification of transportation, and this would culminate with the Congressional approval of the zero-emissions electric mobility law at the end of 2017. New work of a coalition of advocates, experts and representatives in Congress focused on decarbonization of transportation between 2016 and 2018 with a view to take decarbonization to the next level: why not become the first country to go fossil free? Box 4.1 illustrates key developments that set the regulatory framework as well as examples of efforts to engage citizens in the shift to fossil-free transportation.

\section{BOX 4.1 DECARBONIZATION IN REAL LIFE: ENGAGING THE PUBLIC IN ZERO EMISSION ELECTRIC MOBILITY}

Law 9518 provides incentives to zero-emission electric mobility of all types: cars, buses, motorbikes and e-bikes. The incentives apply to zero-emission battery electric transport as well as fuel-cell electric vehicles. It asks the state-owned utility to deploy infrastructure for charging battery electric vehicles by 2020 and to pass additional regulations and standards that are needed to execute the law. A National Plan for Electric Transport, Executive Order 41579 was published in February 2019 to set the basic rules for the deployment of electric vehicle infrastructure, tax benefits for cars and spare parts. The Plan also sets regulations to facilitate future manufacturing and assembly of electric vehicles in Costa Rica.

An electric mobility national commissioner was appointed in 2019 to coordinate governmental activities around e-mobility and engage with the private sector and users. To help bring the ministry on board, in February 2019, the Ministers of Environment and Energy and of Public Works and Transportation signed a sectoral agreement for the transportation sector to work together in the implementation of policies to reduce $4 \mathrm{Mt}$ of $\mathrm{CO}_{2}$ equivalent by 2050 . The measures include public transport and to promote active modes of transportation such as biking and walking, as well as cargo logistics.

Most public charging in Costa Rica is free. In the first phase, about 100 public, semi-fast chargers are in place and about 34 fast chargers are to be in place by 2020. The public-service regulator set up the fee for fast-charging electric vehicles: 183 Costa Rican colones per $\mathrm{kWh}$ (approximately 
US\$0.32).

Several initiatives aim to increase the demand for electric mobility, both public and private. An electric bus pilot project will run three battery-electric buses in 2020 and the utility and Chinese vehicle and battery manufacturer, BYD, are already testing one bus in the capital. A private-sector company is testing a hydrogen bus in Guanacaste province. The feasibility study of a new electric train for great metropolitan area is underway.

Active efforts are in place to stimulate demand for electric vehicles as well: the state-owned utility acquired 100 electric cars. The postal service has started to electrify its fleet of 348 motorbikes. The national insurance company gives a 15 percent discount to electric vehicles. The first electric route for tourists was launched in Monteverde, Puntarenas by community organizers.

Costa Rica Limpia and the Costa Rican Association of Electric Mobility have played an active role in promoting a fossil-free vision for the country by working with Congresswoman Marcela Guerrero who led the legislative process, by breaking myths about the technology, educating public opinion and journalists, and by developing partnerships with the utility and the private sector. They have pioneered the concept of citizen festivals to promote electric mobility since 2017.

\section{A PLAN TO 2050: A GREENER AND MORE INCLUSIVE SOCIETY}

The political case for decarbonization entered a bolder phase in Costa Rica in 2018-20. First, in January 2018, when President Solís (2014-18) signed the new electric mobility law. That sent two powerful signals: one was that climate advocacy worked - the law had been conceived and pushed from the bottom up; it was not the Central Government's initiative - and the second was that incentives for electric mobility by law put Costa Rica in a leadership position because Law 9518 - providing incentives for all forms of electric mobility was the first legislation of its kind in Latin America.

Second, in May 2018, the new president, Carlos Alvarado (2018-22), made international headlines with his inaugural speech by integrating the aspirational narrative of "becoming one of the first countries, if not the first one, to get rid of fossil fuels". This positioned Costa Rica as a country punching above its weight.

Third, in December 2018, the Alvarado administration presented the National Development Plan with its five pillars: economic growth, increasing employment, reducing poverty, decarbonizing the economy and reducing ine- 
quality. For each area, the Plan establishes specific indicators that will be used to report progress each year.

Fourth, the National Decarbonization Plan to 2050 was launched in February of 2019, followed by a citizen fair on decarbonization. This will provide a roadmap for each sector and responds to the Paris Agreement invitation to have mid-century decarbonization strategies by 2020. Costa Rica became one of the first developing countries to have such a strategy. The technical work took place between June 2018 and January 2019, including sectoral consultations. This economy-wide Plan organizes ten transformation routes along four clusters:

(1) transport \& sustainable mobility: (a) public transportation; (b) fleets \& passenger cars; and (c) freight;

(2) energy, green buildings \& industry: (d) power sector; (e) buildings; and (f) industry;

(3) integrated waste management: (g) waste management;

(4) agriculture, land-use change \& nature-based solutions: (h) agriculture; (i) livestock; and (j) biodiversity.

All the actions are organized around three periods: Beginning (2018-22), Inflection $^{1}$ (2023-30) and Massive Deployment (2031-50), with the focus of the current administration on the first phase.

From a sectoral perspective, cluster number one is critical because most of the emissions come from burning gasoline and diesel for transportation. The current approach to transportation is unsustainable, costing around $\$ 691$ million a year due to congestion, $\$ 177$ million due to poor air quality, $\$ 112$ million due to noise and $\$ 17$ million due to carbon pollution. This is only in the great metropolitan area - where nearly 60 percent of the population lives.

\section{Beyond Emissions: Fairness, Inclusion and Human Rights}

Because the transformation of the economy requires structural changes, the Plan complements sectoral routes with cross-cutting strategies in eight areas. This includes, for example, a green reform of the fiscal system, digitalization strategies and in-depth institutional reforms - for example, of the state-owned refinery.

The Plan aims to make Costa Rica a pioneer in the implementation of the Paris Agreement. However, the vision goes beyond a narrow logic of "emission cuts". It aims to build an economy that is green, with zero emissions and resilient but also fair. Costa Rica needs to reduce inequality in a country where about 21 percent of the population is poor. Efforts to green the economy 
need to be designed in a way that does not punish the socially vulnerable communities.

The Plan calls for the assessment of impacts from the measures to decarbonize each sector. It asks for the identification of the impacts of the measures on workers, because heavy impacts could decrease the political viability of decarbonization measures. Understanding the effects of the Plan on the labor market is crucial, according to the Plan, for the development of strategies for the "just transition" of Costa Rican workers. The Ministry of Labor will undertake this work, including the identification of best international practices on "just transition".

Human rights have also become an important priority for climate policy in Costa Rica: the importance of human rights was included in the national contribution to the Paris Agreement and it is one of the cross-cutting strategies of the Decarbonization Plan ("Inclusion, human rights and gender equality"). Some of the measures that it pursues are: encouraging gender parity and the integration of the National Institute for Women in climate governance, and promoting human rights and gender parity in international fora.

Costa Rica has been a champion of the "Regional Agreement on Access to Information, Public Participation and Justice in Environmental Matters in Latin America and the Caribbean", known as the Escazú Agreement. Signed in March 2018, in Escazú, Costa Rica, it is the first in the world containing specific provisions on environmental and human rights defenders. The first meeting of the signatories took place in San José, Costa Rica in October 2019. Given that Latin America is the region where many environmental defenders are murdered, this is a groundbreaking treaty.

\section{FINAL WORDS: TOWARD A GREEN SOCIAL CONTRACT}

How to build a green economy while reducing inequality? This is the defining question of our time and Costa Rica is pioneering both in social and environmental policies. This chapter has provided elements of the effort to combine these policies around a plan to 2050 that was approved in 2019 in response to the Paris Agreement on climate change.

Latin America is extremely vulnerable to climate change and highly unequal. The historical protests in Chile in October of 2019 - with the subsequent suspension of the UN Climate Conference, COP25, in Santiago - marked a watershed in the international community, especially in Latin America. Now more than ever, a big shift is needed to connect the dots and pursue agendas that aim to protect both people and nature.

This chapter has shown that the pioneering efforts to forge a social contract have paid off. The abolition of the army shaped a mindset that favored taking 
a "road less travelled". These political decisions from 1940s left a legacy that was favorable, it has been argued, to the promotion of environmental objectives in the 1970s and 1990s.

This decade, the most ambitious political vision - and plan - aims to make Costa Rica one of the world's first carbon-neutral countries withing a framework of fairness. The National Decarbonization Plan to 2050 offers transformative routes for all the sectors of the economy and includes a broader set of strategies involving inclusiveness, just transition, human rights and gender equality.

The execution of the Plan faces many challenges - for example, it entails a deep transformation of the fiscal architecture and a massive mobilization of financial resources. The Costa Rican experience will be a laboratory for the world not only in terms of decarbonization but also especially in terms of fair decarbonization. If execution goes well, the story of Costa Rica could inspire others to enable a new generation of bold, green social contracts in this defining decade for both the climate and inequality agendas.

\section{NOTE}

1. An inflection in the emissions trajectory.

\section{BIBLIOGRAPHY}

Araya, M. (2016), “A small country with big ideas to get rid of fossil fuels", TED Talks [video], August 15, accessed May 1, 2020 at https://www.ted.com/talks/monica araya_a_small_country_with_big_ideas_to_get_rid_of_fossil_fuels?language $=$ en.

Araya, M. and Rodríguez, C.M. (2018), "The latest science must not paralyze us", Project-syndicate.org, October 8, accessed January 15, 2020 at https://www.project -syndicate.org/commentary/ipcc-report-dire-new-climate-change-conclusions-by -monica-araya-and-carlos-manuel-rodriguez-1-2018-10?barrier=accesspaylog.

Asamblea Legislativa (2018), Ley 9518 de Incentivos al Transporte Eléctrico, accessed January 15, 2020 at http://extwprlegs1.fao.org/docs/pdf/cos177932.pdf.

BBC (2010), "Costa Rica: fallo suspende proyecto de minería a cielo abierto", November 25, accessed May 1, 2020 at https:/www.bbc.com/mundo/noticias/2010/ 11/101124_costa_rica_juicio_mineria_cielo_abierto_amab.

Birkenberg, A. and Birner, R. (2018), "The world's first carbon neutral coffee: lessons on certification and innovation from a pioneer case in Costa Rica", Journal of Cleaner Production, 189, 485-501.

Burgess, M. (2019), “Ad Astra strengthens H2 infrastructure in Costa Rica”, Gas World, April 25, accessed March 1, 2020 at http://www.adastrarocket.com/pressReleases/ 2019/20190820-AdAstra-Aethera.pdf.

Central Bank of Costa Rica (2018), "Cuenta Satélite de Turismo", accessed January 15,2020 at https://www.bccr.fi.cr/seccion-indicadores-economicos/cuenta-sat $\% \mathrm{C} 3$ $\%$ A9lite-de-turismo.

Climate Action Tracker (2019), "Costa Rica”, accessed 20 January 2019 at https:// climateactiontracker.org/countries/costa-rica/current-policy-projections/. 
Dengo, M.E. (2001), Educación Costarricense, San José: EUNED.

EFE (2019), "Costa Rica extiende al año 2050 la moratoria para la exploración y explotación petrolera", February 25, accessed January 15, 2020 at https://www .efe.com/efe/america/economia/costa-rica-extiende-al-ano-2050-la-moratoria-para -exploracion-y-explotacion-petrolera/20000011-3908528.

Estrategia y Negocios (2018), "Grupo Q vende 100 autos eléctricos al ICE en Costa Rica”, December 8, accessed May 1, 2020 at https://www.estrategiaynegocios.net/ empresasymanagement/1240353-330/grupo-q-vende-100-autos-el\%C3\%A9ctricos -al-ice-en-costa-rica December 8.

Government of Costa Rica (2010), "Nota Verbal de la Embajada de Costa Rica en Alemania para la Secretaria de la convención Marco de Cambio Climático de las Naciones Unidas", January 29, accessed August 2019 at https://unfccc.int/files/ meetings/cop_15/copenhagen_accord/application/pdf/costaricacphaccord_app2_2 .pdf.

Government of Costa Rica (2019a), National Decarbonization Plan 2018-2050, San José, February.

Government of Costa Rica (2019b), National Plan for Electric Transportation, San José, February.

Parnell, J. (2013), "Costa Rica sacks climate advisor for criticising China oil loan", Climatechangenews.com, June 19, accessed March 1, 2020 at https:// www.climatechangenews.com/2013/06/19/costa-rica-sacks-climate-advisor-for -criticising-china-oil-loan/.

Rodríguez, E. (1995), Voces del 43, San José: EUNED.

Silva, M. (1989), "La educación de la mujer en Costa Rica durante el siglo XIX", Revista de Historia, No. 20, accessed January 15 at https://www.revistas.una.ac.cr/ index.php/historia/article/view/3265.

Soto, M. (2015), "Ciudadanos de Costa Rica opinaron en consulta mundial sobre el clima" La Nación, June 7, accessed January 15, 2020 at https://www.nacion.com/ ciencia/medio-ambiente/ciudadanos-de-costa-rica-opinaron-en-consulta-mundial -sobre-clima/IH76D2ECYJEUFO3MSFNPAMRERA/story/.

Utgard, B. and Araya, M. (2017), "Electrifying emerging markets: the case of Costa Rica", paper presented at EVS30 Symposium Stuttgart, Germany, October 9-11, accessed March 1, 2020 at https://www.researchgate.net/publication/320434099 _Electrifying_emerging_markets_the_case_of_Costa_Rica. 